\title{
THE PREDICTIVE POWER OF THE YIELD SPREAD UNDER THE VEIL OF TIME
}

\author{
PAOLO ZAGAGLIA \\ Stockholm University and Università Bocconi
}

This version: April 3, 2006

\begin{abstract}
I apply a multiresolution decomposition to the term spread and real-GDP growth in the U.S. Using the filtered data, I study whether the yield spread helps forecasting output. The results show that the predictive power of the yield spread varies largely across time scales both in-sample and out-of-sample at various forecast horizons. Contrarily to the existing literature, I find evidence of a strikingly negative long-run relationship between the spread and future GDP growth over a frequency that spans from 8 to 16 years per cycle. A linear combination among filtered yield spreads shows a sizable improvement in forecasting out-of-sample. The decomposed series are also used for proposing a solution to the breakdown in the in-sample predictive relationship documented by Dotsey (1998) that occurs after 1985.
\end{abstract}

KEYWORDS: wavelets, term structure, predictability

Jel Classification Code: C19, E43, E27

CONTENTS

1 INTRODUCTION 2

2 A REVIEW OF MULTiRESOLUTION ANALYSIS 2

3 PRACTICAL ISSUES $\quad 4$

4 PREDICTING OVER THE FULL SAMPLE 5

4.1 Global predictability ........................ 5

4.2 A negative slope in the long run . . . . . . . . . . . . . . . . . . 6

5 THE FORECAST BREAKDOWN AFTER 1985

6 CONCLUSION 2

Acknowledgements: I am grateful to Erling Steigum, Ulf Söderström and Paul Söderlind for insightful suggestions. I also thank seminar participants at Stockholm University (Department of Economics) and BI Norwegian School of Management for comments. Barbara Rossi and Serena Ng kindly shared their computer codes. Financial support from Stockholm University and MIUR is gratefully acknowledged. This paper was written while I was visiting Università Bocconi and the University of Bologna. I thank both institutions for their kind hospitality. Updated versions of this paper are available from the author's webpages. All the errors are the author's sole responsibility. 


\section{INTRODUCTION}

Estrella and Hardouvelis (1991) have established the usefulness of the yield spread for forecasting output growth. A positive slope of yield curve - i.e. a positive spread between long-term and short-term interest rates - successfully explains the future growth of real GDP up to 16 quarters ahead, depending on the measure of output growth adopted. Stock and Watson (2003) find that the yield spread is also a good predictor for future output growth out-of-sample. Two aspects of the predictive relationship are worth stressing. First, there is evidence of a fall in the in-sample fit starting from 1985 (see Dotsey, 1998). Second, the estimated parameters of the predictive regressions are unstable over the full post-war sample Giacomini and Rossi (2005).

This paper re-considers the predictive power of the yield curve across time-frequencies. The aim is to understand what components of the time pattern in the predictive relation explain its success or failure. I apply a multiresolution decomposition to the quarterly series for real GDP and the term spread in the U.S. The data sample spans from the first quarter of 1954 to the first quarter of 2001. Then, I study the predictive regressions based on these filtered series. The methodological framework used here is not new. For instance, Deng (2005) uses wavelet-based filtering for the prediction of stock returns using the dividend-price ratio. From a more general point of view, empirical applications with wavelets have florished lately, Crowley and Lee (2005) and Crowley, Maraun, and Mayes (2005) being only two examples.

The results indicate that the predictive ability of the decomposed yield spread for unfiltered output growth varies largely across time scales. Using a linear combination of the decomposed spread as predictor for unfiltered GDP growth, I find a sizeable improvement in both in-sample and out-of-sample forecasts. I investigate the heterogeneity in predicting ability by regressing filtered output growth on the filtered yield spread at each time scale. A remarkable result emerges. For series that include cycles with frequency spanning from 8 to 16 years, the relation between future output growth and the slope of the yield curve is significantly negative over the full sample. Plots of the filtered series indicate that this is a key feature of the relation between output growth and the yield spread before 1985. For a subsample starting in 1985, the predictive relation has the expected positive sign. The decomposed series are also used for proposing a solution to the breakdown of in-sample fit documented by Dotsey (1998) that occurs after 1985.

This paper is organized as follows. Section 2 provides a broad overview of the technique of multiresolution decomposition used in the remaining sections. Section 3 describes the dataset and the properties of the filtered series. Then, I analyze the details of the predictive content of the filtered term spread both in-sample, and out-of-sample. In section 4, I discuss a possible resolution of the forecast breakdown after 1985 based on filtered regressors. Section 5 presents some concluding remarks.

\section{A REVIEW OF MULTIRESOLUTION ANALYSIS}

The following is intended as a non-exhaustive summary of the foundations of multiresolution analysis. I provide results on the connections between time-scale decomposition and wavelet functions. For a more thorough overview, the reader can refer to Debauchies (1992), which is the standard reference for the mathematical properties of multiresolution analysis through wavelets. A compact review of the topic with sample of economic applications can be found in Ramsey (1999) and Crowley (2005).

The aim of multiresolution analysis consists in the approximation of signals. A time series is decomposed into a smooth component, that represents the long-run trend, and fluctuations or details, that identify the short-run movements. The distinction between the smooth and the fluctuating parts is determined by the resolution, that is the time scale below which the details 
cannot be detected. At each scale, the multiresolution decomposition approximates a time series by ignoring the details at the lower scales. The approximation of the signal improves by adding finer details at higher time scales.

In order to fix the notation, denote by $f(t)$ the signal to decompose. The time scale takes on values from $(1 / 2)^{j}$, where $j$ is the (integer) resolution level. The $j$-level approximation of the signal is $f_{j}(t)$. The approximation at $j+1$ is a function of the detail level $d_{j}(t)$ :

$$
f_{j+1}(t)=f_{j}(t)+d_{j}(t)
$$

Recursive substitution within this expression suggests the way of recovering the original signal. As the resolution goes to infinity, the raw signal is obtained.

The principles of multiresolution analysis generalize to function spaces. Let $\mathrm{L}^{2}(\mathbf{R})$ denote the space of square-integrable functions. The multiresolution decomposition of $\mathrm{L}^{2}(\mathbf{R})$ consists of the sequences of subspaces $\left\{\mathrm{W}_{k}\right\}_{k=j}^{\infty}$ and $\mathrm{V}_{j}$ such that $f_{j}(t) \in \mathrm{V}_{j}$ and $d_{k}(t) \in\left\{\mathrm{W}_{k}\right\}_{k=j}^{\infty}$. The following theorem establishes the conditions of a multiresolution analysis.

THEOREM 1: A multiresolution analysis of $\mathrm{L}^{2}(\mathbf{R})$ is a nested sequence of subspaces $\left\{\mathrm{V}_{j}\right\}_{j \in \mathrm{Z}}$ such that:

- The information at level $j$ is included in the information at finer resolutions: ... $\subset \mathrm{V}_{-1} \subset$ $\mathrm{V}_{0} \subset \mathrm{V}_{1} \subset \mathrm{L}^{2}(\mathbf{R})$

- All the integrable functions should be included at the highest resolution: $\cap_{j} \mathrm{~V}_{j}=\emptyset, \overline{\cup_{j} \mathrm{~V}_{j}}=$ $\mathrm{L}^{2}(\mathbf{R})$

- (dilation invariance) Re-scaling from the central space $\mathrm{V}_{0}$ generates all the spaces $\left\{\mathrm{V}_{j}\right\}_{j \in \mathrm{Z}}$ : $f(t) \in \mathrm{V}_{j} \Longleftrightarrow f(2 t) \in \mathrm{V}_{j}$

- (translation invariance) $f(t) \in \mathrm{V}_{0} \Longrightarrow f(t-k) \in \mathrm{V}_{0}$

- There exists a scaling function $\phi(t)$ such that $\{\phi(t-k)\}$ is an orthonormal basis for $\mathrm{V}_{0}$.

Through translation invariance, it is possible to generate a set of functions that are orthonormal basis for $\left\{\mathrm{V}_{j}\right\}_{j \in \mathrm{Z}}$ :

$$
\phi_{j, k}(t):=2^{j / 2} \phi\left(2^{j} t-k\right)
$$

The level $j$ controls the degree of stretching of the function. The larger the $j$, the more stretched is the basis function. The smaller the time scale, the higher the frequency of the decomposed series (see Table I), the less stretched the basis function. The parameter $k$ determines the location of the basis function. Time localization captures the information of each form of noise separately at each frequency. This property implies that any locally-inhomogenous behavior affects only a few coefficients of the transformation.

Let us assume that the detail spaces $\left\{\mathrm{W}_{j}\right\}$ are orthogonal to each other. Like for the approximation spaces, we can define a sequence $\left\{\psi_{j, k}(t)\right\}_{k}$ of orthonormal basis functions that spans $\mathrm{L}^{2}(\mathbf{R})$ :

$$
\psi_{j, k}(t):=2^{j / 2} \psi\left(2^{j} t-k\right)
$$

The function $\psi_{j, k}(t)$ is called wavelet. Like the set of scaling functions, wavelets are generated by dilation and translation from a mother wavelet $\psi(t)$.

In the analysis presented in this paper, the assumption of orthogonality among detail spaces is relaxed, and biorthogonal wavelet functions are used. In order to allow the decomposition 
of a function space by linear combination of nonorthogonal basis, dual multiresolution analysis introduces the dual subspaces $\left\{\tilde{\mathrm{W}}_{k}\right\}_{k=j}^{\infty}$ and $\left\{\tilde{\mathrm{V}}_{j}\right\}_{j \in Z}$. These are generated, respectively, from a dual scaling function $\tilde{\phi}(t)$ and a dual mother wavelet $\tilde{\psi}(t)$. Given an inner product $\langle\cdot\rangle$ on $\mathbf{L}^{2}(\mathbf{R})$, the conditions for biorthogonality take the form:

$$
\begin{array}{ll}
\left\langle\tilde{\phi}_{j, k} \tilde{\phi}_{j, l}\right\rangle=\delta_{k, l} \quad \text { and } \quad\left\langle\tilde{\psi}_{j, k} \tilde{\psi}_{j^{\prime}, l}\right\rangle=\delta_{j, j^{\prime}} \delta_{k, l} \\
\left\langle\tilde{\psi}_{j, k} \phi_{j, l}\right\rangle=0 \quad \text { and } \quad\left\langle\tilde{\phi}_{j, k} \psi_{j, l}\right\rangle=0
\end{array}
$$

where: $\tilde{\phi}_{j, k}(t):=2^{j / 2} \tilde{\phi}\left(2^{j} t-k\right)$ and $\tilde{\psi}_{j, k}(t):=2^{j / 2} \tilde{\psi}\left(2^{j} t-k\right)$.

Summing up, the biorthogonal wavelet decomposition of a time series $f(t)$ can be written as:

$$
\begin{aligned}
& f(t)=\sum_{k} s(J, k) \phi(t, J, k)+\sum_{j} \sum_{k} d(j, k) \psi(t, j, k)=A_{J}+D_{J}+D_{J-1} \ldots+D_{1} \\
& s(J, k):=\sum_{t} \phi(t, J, k) f(t) \\
& d(j, k):=\sum_{t} \psi(t, j, k) f(t)
\end{aligned}
$$

The discrete wavelet transform of $f(t)$ is summarized by the set: $\left\{A_{J}, D_{J-1} \ldots, D_{1}\right\}$. The term $A_{J}$ is a level approximation that captures the long-run (trending) properties of the signal. Given a decomposition scaling function $\tilde{\phi}(t, J, k)$ and a reconstruction scaling function $\tilde{\psi}(t, J, k), A_{J}$ can be written as:

$$
A_{J}=\sum_{k}[\tilde{\phi}(t, J, k) f(t)] \tilde{\psi}(t, J, k)
$$

The level components $D_{j}$ focus on high-resolution properties of the series. They are constructed in a way analogous to that of the level approximation:

$$
D_{j}=\sum_{k}[\phi(t, j, k) f(t)] \psi(t, j, k)
$$

The biorthogonal wavelet transform makes use of four types of functions. One type - decomposition scaling and decomposition wavelet function - is needed for decomposing the signal. The other type - reconstruction scale and reconstruction wavelet function - is used for reconstructing the series.

Yogo (2003) argues that the choice of the wavelet filter should not affect the behavior of the series extracted at each time scale. The filter should also be sufficiently long so that no artificial properties are generated both for filtering and for reconstruction. Yogo (2003) finds that a lowpass filter with 17 periods as the length, and a highpass filter with 11 periods performs quite well for the decomposition of real output. In this case, the wavelet and the band-pass decompositions are very similar. Like Deng (2005), I apply the 17-11 filter bank.

\section{PRACTICAL ISSUES}

I use quarterly data obtained from the FREDII online database of the Federal Reserve Bank of St Louis. The sample spans from the first quarter of 1954 to the fourth quarter of 2001. The yield spread is computed as the difference between the 10-year yield and the 3-month yield. This definition of the spread has been standard practice since the seminal work of Estrella and Hardouvelis (1991), and is applied here for comparison with the literature. 
The wavelet decomposition is applied to the level of the real GDP index, and to each of the bond yields separately. The filtered series for GDP growth and the yield spread at every predictive horizon are computed afterwards.

The discrete wavelet transform can be applied to sample sizes that are multiples of $m$ power of 2. My sample size is 192 , which entails a decomposition up to level $6\left(3 \times 2^{6}\right)$. Finally, I should point out that the wavelet decomposition introduces some distortion at the end of the filtered series. The reason lies in the wave-like periodic shape of the transformation, which is interrupted independently from the location along the wave. Like most empirical studies, I disregard this issue.

Figures 1 and 2 show the decomposition of the series. As expected, details at level 1 and 2 identify the most noisy components. The approximations pick up the (possibly nonlinear) trends. The level decomposition from 1 to 3 captures the large outliers in the interest rate series in coincidence with the two episodes of large inversion of the yield curve in the first half of the 1980s.

\section{PREDicting OVER THE FULL SAMPLE}

This section studies the predictive relation between future output growth and the yield spread at each level of decomposition over the entire sample. The model takes the standard regression form:

$$
[400 / h] \ln \left[\frac{y_{t+h}}{y_{t}}\right]=\alpha+\beta s_{t}+\epsilon_{t+h}
$$

where and $s_{t}$ is the term spread. The standard errors are estimated through the covariance estimator proposed by Newey and West (1987). The predictive ability of the yield spread is examined through the usual $t$-statistic, like in Ramsey and Lampart (1998). For brevity, I discuss the results for selected predictive horizons only.

\subsection{Global predictability}

The first column of Table II displays the well-known result of in-sample predictability for the unfiltered data. All the estimates of the slope coefficients are statistically significant and have the expected positive sign. The estimated $R^{2}$ statistics are somewhat lower than what found in previous studies like Estrella and Hardouvelis (1991). This is due to the fact that the sample used here includes the period of predictability breakdown starting in 1985 (see Dotsey, 1998).

The rest of Table II shows the results from regressing unfiltered future output growth on the filtered yield spread at each decomposition level. It is clear that the pattern of predictability is not homogenous across time scales. The slope coefficients for the regressions at the levels A6, D1 and D6 are statistically not different from zero for all the predictive horizons. The yield spread at the levels D4 and D5 appear as good predictors, both in terms of statistical significance of the relation and in terms of $R^{2}$. The long-term relationship between the term spread and future output growth at A6 and D6 is negative, although not significant.

Can the finding of time-heterogeneity be used to improve the in-sample fit of the predictive model? In order to answer this question, I follow the idea suggested by Deng (2005) for studying the predictive relation between prices and dividend-price ratios of stocks. The intuition goes as follows. Since the statistical properties of the predictive models for output growth vary across time scales, I can look for a linear combination among the level components of the yield spread that have a statistically significant predictive power. In other words, the aim is that of finding a filtered regressor that removes the 'noisy' components of the predictive regressor at each time scale. I compute this filtered regressor as the sum of level components whose estimated slopes are statistically significant at the $5 \%$ level. This variable is then used to predict unfiltered output growth. For instance, predictions for two quarters ahead use the sum between crystals at levels D2, 
D4 and D5 as the regressor. Table III shows that there are large gains from following this strategy. First, the proposed filtered predictors perform very well in-sample even at long predictive horizons. Second, the sum among the statistically significant regressors has a predictive power larger than that of each level regressor from Table II.

The subsequent question of interest is whether the filtered series can be used for forecasting out-of-sample. Thus, I compute the tests for forecasting comparisons of nested models proposed by Clark and McCracken (2001). Like in Stock and Watson (2003), the nested model postulates that output growth is unpredictable in that it follows a random walk. This idea is formalized by imposing $\hat{\alpha}=0$ and $\hat{\beta}=0$. The forecast-encompassing tests are applied to split-sample, recursive and rolling forecasting schemes. The null is that the nested and non-nested model have equal predictive ability.

Encompassing tests cannot be applied to nonstationary data (see Kilian, 1999). Hence, I apply the variants of the tests of Dickey and Fuller (1979) and Phillips and Perron (1988) proposed by Perron and Ng $(1996,2001)$ for the null of a unit root. These tests retain power in small samples through the use of a set of selection criteria for the order of the underlying autoregression. The results are reported in a statistiscal annex available upon request. They indicate strong rejections of the null of a unit root for the unfiltered yield spread at all predictive horizons. There is evidence of nonstationarity for the raw series of output growth only up to a predictive horizon of 4 quarters ahead. I calculate the first difference of the variables that are nonstationary before computing the nested models.

Table IV reports the results from a battery of tests for a one-time structural break, namely the tests of Andrews (1993), Andrews and Ploberger (1993) and Nyblom (1989). The null is that of parameter stability. The low $p$-values suggest that both models with unfiltered and filtered regressors suffer from structural instability. Hence, the reader should focus on the forecast-encompassing tests based on rolling-windows estimates, which are known to be robust to parameter instability. Unfiltered regressors have no predictive power out-of-sample for 6 and 8 quarters ahead (see Table IV). The use of the predictive regressors restores the predictive power over all the horizons.

\subsection{A negative slope in the long run}

The previous section has established that the predictive power of the yield spread for unfiltered output growth varies across time scales. In this section, I investigate further the implications of the heterogeneity in the predictive relation. I regress filtered output growth on the filtered yield spread at each level. Table $\mathrm{V}$ shows that the quality of the predictive relation changes largely over time scales.

In opposition to the standard results, for a time scale between 8 and 16 years, the slope of the predictive regressions are negative and largely significant (see Table V). This result holds both for the detail D6 and the level approximation A6, that is both for details at long cycles and for the trend. In the former, the elasticity of future output growth to the yield spread is negative. In the latter, the elasticity is positive over all the predictive horizons owing to the large estimated constant terms.

Figure 3 indicates that, especially for the A6 components, the negative relation between output growth and the yield spread is an evident feature of the data until 1985. Following this hint, I compute the level regressions for both the pre-1985 and the post-1985 period. Table VI replicates all the findings that emerge from table V. Since the results from the pre-1985 regressions are standard (included in the unpublished appendix), I can conclude that the negative slope of the predictive model is due to features of the data that are present only in the pre- 1985 subsample. 


\section{THE FORECAST BREAKDOWN AFTER 1985}

Dotsey (1998) and Haubrich and Dombrosky (1996) report substantial evidence of a fall in the predictive power of the term spread since 1985. Ang, Piazzesi, and Wei (2005) show that the short-term rate is a better predictor for output growth than the yield spread during the 1990s. In what follows, I investigate the question of forecast breakdown from a time-scale perspective. I divide the full sample into pre-1985 and post-1985 subsamples, and compute predictive regressions along the lines developed in the previous sections.

Like for the full sample, table VII shows that the statistical significance of the regressions with filtered yield spread varies largely over time scales. This suggests a way out of the in-sample predictive breakdown after 1985, namely that of using an appropriate level component for the term spread in the predictive model. In particular, the table indicates that the D4-component of the yield spread is the best candidate, in that it is a significant predictor for output growth for up to 10 quarters ahead. I have also checked whether in-sample fit can be improved by regressing the unfiltered output growth on the sum of level regressors whose estimated regression slopes are significant at the $5 \%$ level. Differently from the full sample, no relevant results have emerged.

The issue is whether the filtered yield spread can help predicting out-of-sample. Both the tests for structural stability and the forecast-encompassing tests suggest that no gains in terms of out-of-sample forecasts are achieved by using filtered regressors.

\section{CONCLUSION}

In this paper, I revisit the relation of predictability between the yield spread and output growth at several forecasting horizons. I show that the predictive relation is heterogeneous across time scales. For a time scale between 8 to 16 years, a negative slope of the yield curve translates into positive GDP growth in the future in contrast to the existing literature. There is a linear combination of decomposed series for the yield spread that predicts output growth out-of-sample more accurately than the unfiltered regressor. Finally, I propose a solution to the breakdown of in-sample fit after 1985 through the use of a filtered regressor.

Several extensions are on the agenda. The question of primary interest is why the negative slope in the very long run explains future changes in output well. The issue of parameter instability is not solved through wavelet-filtered regressors. Giacomini and Rossi (2005) argue that the instability in predicting growth can be related to monetary policy conduct of the Fed. It would be interesting to check whether their conjecture applies to the analysis of monetary policy over time scales. 
Paolo Zagaglia: Department of Economics, Stockholm University, Universitetsvägen 10A; SE10691 Stockholm, Sweden; Università Bocconi, via Sarfatti 25, 20136 Milano, Italy; Phone: +468-16 42 42-Web: http://www.ne.su.se/ pzaga-E-mail: pzaga@ne.su.se

\section{REFERENCES}

Andrews, D. W. K. (1993): "Tests for Parameter Instability and Structural Chage with Unknown Change Point," Econometrica, 61.

Andrews, D. W. K., And W. Ploberger (1993): "Optimal Tests when a Nuisance Parameter is Present only under the Alternative," Econometrica, 61.

Ang, A., M. Piazzesi, And M. Wei (2005): "What Does the Yield Curve Tell Us About GDP Growth?," Journal of Econometrics, forthcoming.

Clark, T., And M. MCCracken (2001): "Tests of Equal Forecast Accuracy and Encompassing for Nested Models," Journal of Econometrics, 105.

Crowley, P. (2005): "An Intuitive Guide to Wavelets for Macroeconomists," Bank of Finland Working Paper, 1.

Crowley, P., And J. Lee (2005): "Decomposing the Comovement of the Business Cycle: A TimeFrequency Analysis of Growth Cycles in the Euro Area," Bank of Finland Working Paper, 12.

Crowley, P., D. Maraun, And D. Mayes (2005): "Analysing Productivity Cycles in the Euro Area, US and UK Using Wavelet Analysis," unpublished manuscript, Bank of Finland.

Debauchies, I. (1992): Ten Lectures on Wavelets. Capital City Press.

Deng, A. (2005): "Decomposing Predictability: A Multiresolution Analysis," unpublished manuscript, Boston University.

Dickey, D. A., And W. A. Fuller (1979): "Distribution of the Estimators for Autoregressive Time Series with a Unit Root," Journal of the American Statistical Association, 74.

Dotsey, M. (1998): "The Predictive Content of the Interest Rate Term Spread for Future Economic Growth," Federal Reserve Bank of Richmond Economic Quarterly, 84.

Estrella, A., And G. A. Hardouvelis (1991): "The Term Structure as a Predictor of Real Economic Activity," Journal of Finance, XLVI.

Giacomini, R., And B. Rossi (2005): "How Stable is the Forecasting Performance of the Yield Curve for Output Growth?," unpublished manuscript, UCLA and Duke University.

Haubrich, J. G., And A. M. Dombrosky (1996): "Predicting Real Growth Using the Yield Curve," Federal Reserve Bank of Cleveland Economic Review, 32.

KiLIAn, L. (1999): "Exchange Rates and Monetary Fundamentals: What Do We Learn From Long-Horizon Regressions?," Journal of Applied Econometrics, 14.

Newey, W., And K. J. West (1987): "A simple, positive semi-definite, heteroskedasticity and autocorrelation consistent covariance matrix," Econometrica, 55.

Nyblom, J. (1989): "Testing for the Constancy of Parameters over Time," Journal of the American Statistical Association, 84.

Perron, P., And S. NG (1996): "Useful Modifications to Unit Root Tests with Dependent Errors and Their Local Asymptotic Properties," Review of Economic Studies, 63. 
(2001): "Lag Length Selection and the Construction of Unit Root Tests with Good Size and Power," Econometrica, 69.

Phillips, P. C. B., And P. Perron (1988): "Testing for a Unit Root in Time Series Regression," Biometrika, 75 .

Ramsey, J. B. (1999): "The Contribution of Wavelets to the Analysis of Economic and Financial Data," Philosophycal Transactions of the Royal Statistical Society, 357.

Ramsey, J. B., And C. LAmpart (1998): "The Decomposition of Economic Relationships by Time Scale Using Wavelets: Expenditure and Income," Studies in Nonlinear Dynamics and Econometrics, 3.

Stock, J., And M. W. Watson (2003): "Forecasting Output and Inflation: The Role of Asset Prices," Journal of Economic Literature, 41.

Yogo, M. (2003): "Measuring Business Cycles: Wavelet Analysis of Economic Time Series," unpublished manuscript, Harvard University. 

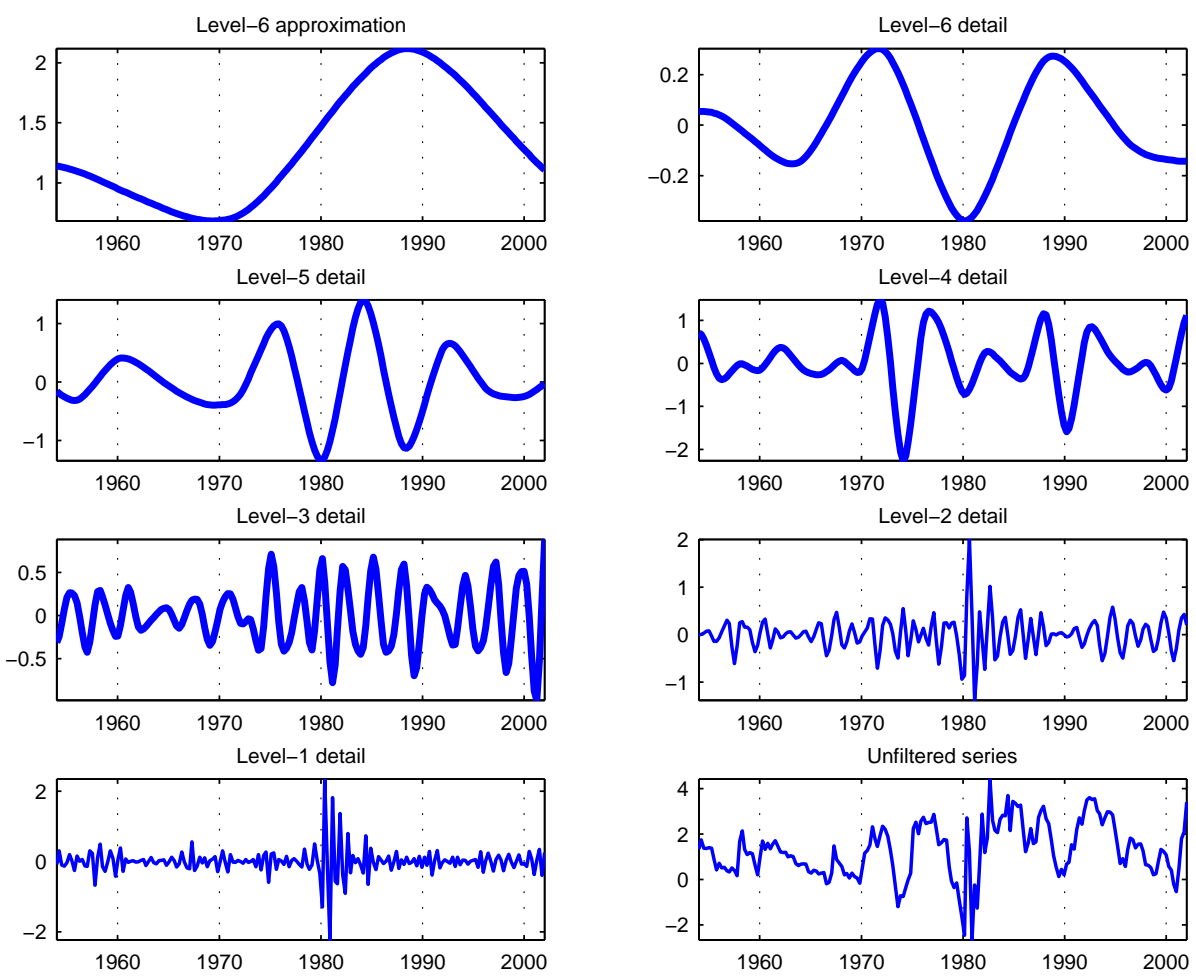

Figure 1-: Time-scale decomposition for the 10-year yield spread 

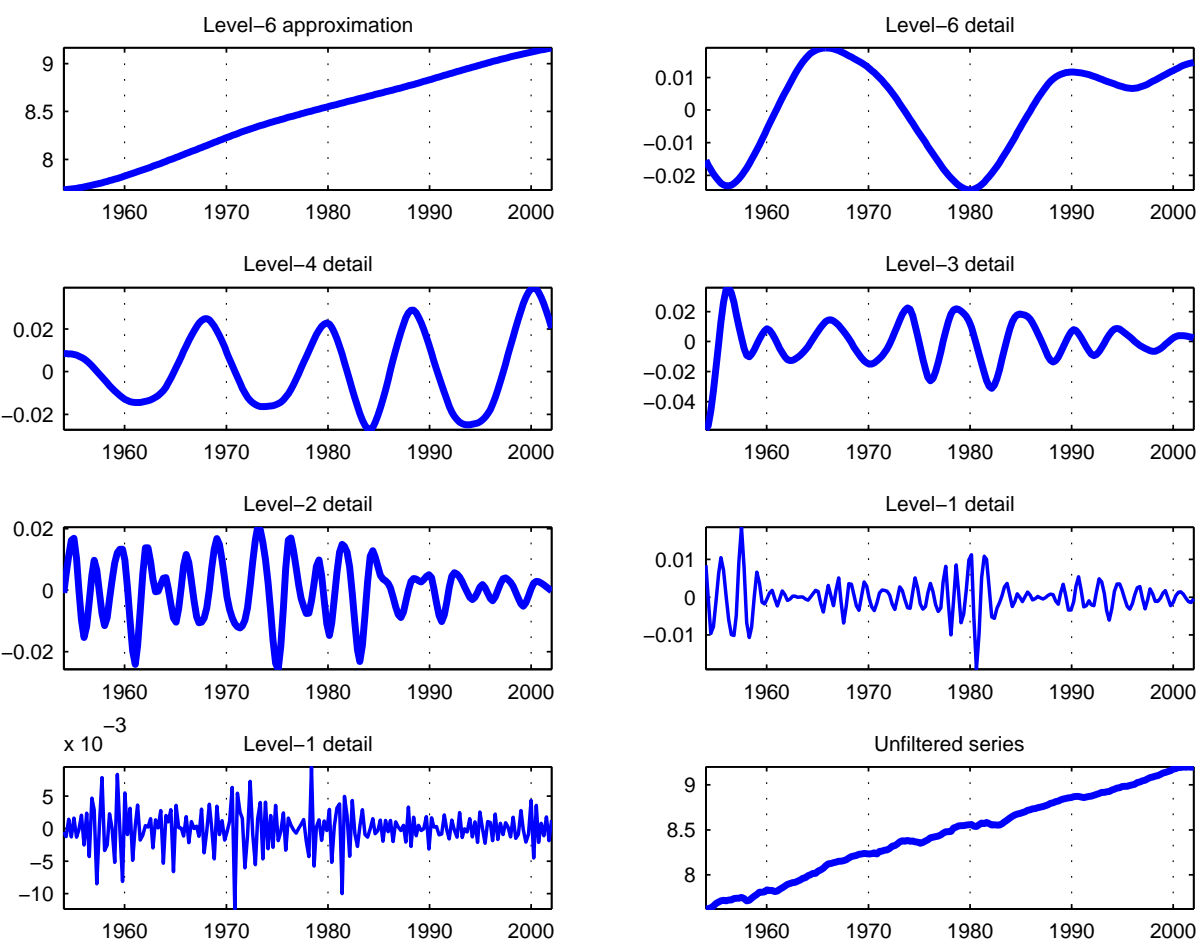

Figure 2-: Time-scale decomposition for the level of GDP 

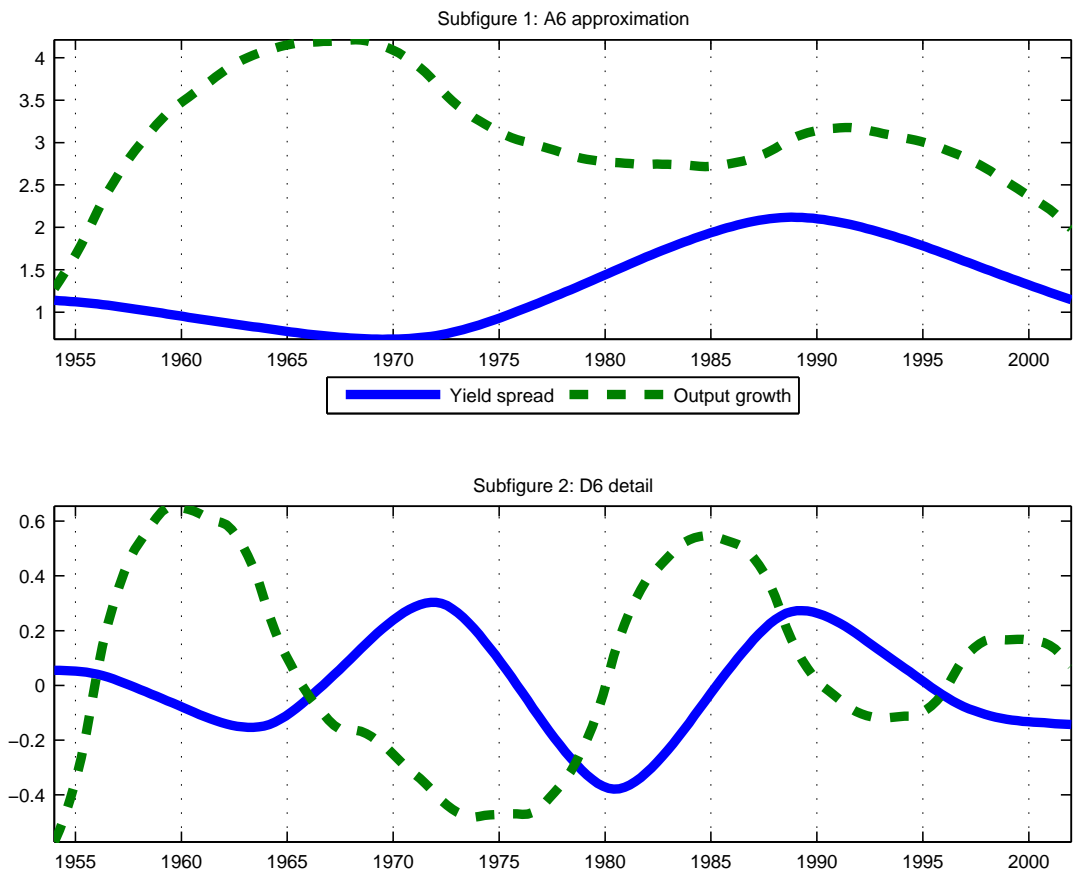

Figure 3-: Plots of decompositions at A6 and D6 
TABLE I:

FREQUENCY INTERPRETATION OF TIME SCALES

\begin{tabular}{cc}
\hline \hline Component & $\begin{array}{c}\text { Quarterly-frequency } \\
\text { resolution }\end{array}$ \\
\hline D1 & $1-2$ quarters \\
D2 & $2-4$ quarters \\
D3 & $1-2$ years \\
D4 & $2-4$ years \\
D5 & $4-8$ years \\
D6 & 8-16 years \\
\hline \hline
\end{tabular}


TABLE II:

Predictive models With LeVel Regressors, FUll SAMPle

\begin{tabular}{|c|c|c|c|c|c|c|c|c|}
\hline & Unfiltered & $\mathrm{A} 6$ & D1 & D2 & D3 & D4 & D5 & D6 \\
\hline \multicolumn{9}{|l|}{$h: 2$} \\
\hline$\hat{\alpha}$ & $\begin{array}{l}2.15 \\
(4.73)\end{array}$ & $\begin{array}{l}3.98 \\
(4.22)\end{array}$ & $\begin{array}{l}3.32 \\
(9.90)\end{array}$ & $\begin{array}{c}3.32 \\
(10.11)\end{array}$ & $\begin{array}{l}3.33 \\
(9.97)\end{array}$ & $\begin{array}{c}3.33 \\
(11.27)\end{array}$ & $\begin{array}{c}3.33 \\
(10.14)\end{array}$ & $\begin{array}{l}3.32 \\
(9.96)\end{array}$ \\
\hline$\hat{\beta}$ & $\begin{array}{l}0.91 \\
(3.97)\end{array}$ & $\begin{array}{l}-0.50 \\
(-0.82)\end{array}$ & $\begin{array}{l}0.34 \\
(0.68)\end{array}$ & $\begin{array}{l}1.92 \\
(2.61)\end{array}$ & $\begin{array}{l}0.94 \\
(1.08)\end{array}$ & $\begin{array}{l}1.81 \\
(5.93)\end{array}$ & $\begin{array}{l}0.88 \\
(1.76)\end{array}$ & $\begin{array}{l}-0.44 \\
(-0.21)\end{array}$ \\
\hline$R^{2}$ & 0.12 & 0.01 & 0.002 & 0.05 & 0.01 & 0.14 & 0.03 & 0.0001 \\
\hline \multicolumn{9}{|l|}{$h: 4$} \\
\hline$\hat{\alpha}$ & $\begin{array}{l}2.20 \\
(4.96)\end{array}$ & $\begin{array}{l}3.99 \\
(4.32)\end{array}$ & $\begin{array}{c}3.33 \\
(10.23)\end{array}$ & $\begin{array}{c}3.34 \\
(10.30)\end{array}$ & $\begin{array}{c}3.33 \\
(10.34)\end{array}$ & $\begin{array}{c}3.36 \\
(12.55)\end{array}$ & $\begin{array}{c}3.35 \\
(10.89)\end{array}$ & $\begin{array}{c}3.33 \\
(10.32)\end{array}$ \\
\hline$\hat{\beta}$ & $\begin{array}{c}0.89 \\
(4.00)\end{array}$ & $\begin{array}{l}-0.50 \\
(-0.82)\end{array}$ & $\begin{array}{l}-0.06 \\
(-0.25)\end{array}$ & $\begin{array}{l}0.97 \\
(2.02)\end{array}$ & $\begin{array}{l}1.63 \\
(2.11)\end{array}$ & $\begin{array}{c}1.88 \\
(7.31)\end{array}$ & $\begin{array}{l}1.05 \\
(2.40)\end{array}$ & $\begin{array}{l}-0.66 \\
(-0.30)\end{array}$ \\
\hline$R^{2}$ & 0.19 & 0.01 & 0.00001 & 0.02 & 0.04 & 0.25 & 0.06 & 0.00 \\
\hline \multicolumn{9}{|l|}{$h: 6$} \\
\hline$\hat{\alpha}$ & $\begin{array}{l}2.33 \\
(5.30)\end{array}$ & $\begin{array}{l}3.95 \\
(4.65)\end{array}$ & $\begin{array}{c}3.33 \\
(10.92)\end{array}$ & $\begin{array}{c}3.33 \\
(10.91)\end{array}$ & $\begin{array}{c}3.32 \\
(10.83)\end{array}$ & $\begin{array}{c}3.35 \\
(12.82)\end{array}$ & $\begin{array}{c}3.34 \\
(12.27)\end{array}$ & $\begin{array}{c}3.32 \\
(11.08)\end{array}$ \\
\hline$\hat{\beta}$ & $\begin{array}{c}0.77 \\
(3.62)\end{array}$ & $\begin{array}{l}-0.48 \\
(-0.84)\end{array}$ & $\begin{array}{l}-0.06 \\
(-0.35)\end{array}$ & $\begin{array}{l}0.25 \\
(0.78)\end{array}$ & $\begin{array}{l}1.32 \\
(1.81)\end{array}$ & $\begin{array}{l}1.63 \\
(6.87)\end{array}$ & $\begin{array}{l}1.19 \\
(2.83)\end{array}$ & $\begin{array}{l}-0.91 \\
(-0.40)\end{array}$ \\
\hline$R^{2}$ & 0.21 & 0.01 & 0.0001 & 0.002 & 0.04 & 0.27 & 0.12 & 0.01 \\
\hline \multicolumn{9}{|l|}{$h: 8$} \\
\hline$\hat{\alpha}$ & $\begin{array}{l}2.50 \\
(5.87)\end{array}$ & $\begin{array}{l}3.92 \\
(4.96)\end{array}$ & $\begin{array}{c}3.32 \\
(11.54)\end{array}$ & $\begin{array}{c}3.32 \\
(11.53)\end{array}$ & $\begin{array}{c}3.32 \\
(11.51)\end{array}$ & $\begin{array}{c}3.33 \\
(12.41)\end{array}$ & $\begin{array}{c}3.33 \\
(13.66)\end{array}$ & $\begin{array}{c}3.32 \\
(11.78)\end{array}$ \\
\hline$\hat{\beta}$ & $\begin{array}{l}0.63 \\
(3.36)\end{array}$ & $\begin{array}{l}-0.46 \\
(-0.87)\end{array}$ & $\begin{array}{l}0.06 \\
(0.43)\end{array}$ & $\begin{array}{l}0.15 \\
(0.63)\end{array}$ & $\begin{array}{l}0.69 \\
(1.26)\end{array}$ & $\underset{(5.81)}{1.23}$ & $\begin{array}{l}1.27 \\
(3.22)\end{array}$ & $\begin{array}{l}-1.12 \\
(-0.50)\end{array}$ \\
\hline$R^{2}$ & 0.19 & 0.02 & 0.0002 & 0.001 & 0.02 & 0.22 & 0.18 & 0.01 \\
\hline \multicolumn{9}{|c|}{$h: 10$} \\
\hline$\hat{\alpha}$ & $\begin{array}{l}2.71 \\
(6.70)\end{array}$ & $\begin{array}{l}3.91 \\
(5.17)\end{array}$ & $\begin{array}{c}3.33 \\
(12.12)\end{array}$ & $\begin{array}{c}3.33 \\
(12.12)\end{array}$ & $\begin{array}{c}3.33 \\
(12.12)\end{array}$ & $\begin{array}{c}3.33 \\
(12.35)\end{array}$ & $\begin{array}{c}3.33 \\
(14.79)\end{array}$ & $\begin{array}{c}3.33 \\
(12.41)\end{array}$ \\
\hline$\hat{\beta}$ & $\begin{array}{l}0.47 \\
(2.93)\end{array}$ & $\begin{array}{l}-0.44 \\
(-0.89)\end{array}$ & $\begin{array}{l}-0.02 \\
(-0.17)\end{array}$ & $\begin{array}{l}0.14 \\
(0.81)\end{array}$ & $\begin{array}{l}0.31 \\
(0.70)\end{array}$ & $\begin{array}{c}0.82 \\
(4.19)\end{array}$ & $\begin{array}{l}1.28 \\
(3.64)\end{array}$ & $\begin{array}{l}-1.26 \\
(-0.59)\end{array}$ \\
\hline$R^{2}$ & 0.14 & 0.02 & 0.00001 & 0.001 & 0.0001 & 0.13 & 0.25 & 0.02 \\
\hline \multicolumn{9}{|c|}{$h: 12$} \\
\hline$\hat{\alpha}$ & $\begin{array}{l}2.85 \\
(7.41)\end{array}$ & $\begin{array}{l}3.89 \\
(5.32)\end{array}$ & $\begin{array}{c}3.33 \\
(12.63)\end{array}$ & $\begin{array}{c}3.33 \\
(12.64)\end{array}$ & $\begin{array}{c}3.33 \\
(12.62)\end{array}$ & $\begin{array}{c}3.32 \\
(12.63)\end{array}$ & $\begin{array}{c}3.33 \\
(15.49)\end{array}$ & $\begin{array}{c}3.33 \\
(12.95)\end{array}$ \\
\hline$\hat{\beta}$ & $\begin{array}{l}0.36 \\
(2.43)\end{array}$ & $\begin{array}{l}-0.43 \\
(-0.90)\end{array}$ & $\begin{array}{l}0.05 \\
(0.73)\end{array}$ & $\begin{array}{l}0.25 \\
(1.58)\end{array}$ & $\begin{array}{l}0.28 \\
(0.75)\end{array}$ & $\begin{array}{c}0.44 \\
(2.50)\end{array}$ & $\begin{array}{l}1.24 \\
(4.18)\end{array}$ & $\begin{array}{l}-1.37 \\
(-0.67)\end{array}$ \\
\hline$R^{2}$ & 0.11 & 0.03 & 0.0002 & 0.004 & 0.0001 & 0.05 & 0.29 & 0.03 \\
\hline
\end{tabular}

Legend: Round brackets indicate $t$-values. 
TABLE III:

Predictive Models With FiLtered Regressors, Full SAMPle

\begin{tabular}{ccccccc}
\hline \hline & \multicolumn{7}{c}{$h$} \\
\cline { 2 - 7 }$\hat{\alpha}$ & $2^{a}$ & $4^{b}$ & $6^{c}$ & $8^{c}$ & $10^{d}$ & $12^{a}$ \\
\cline { 2 - 7 }$\hat{\beta}$ & 3.35 & 3.37 & 3.35 & 3.33 & 3.33 & 3.33 \\
& $11.67)$ & $(13.77)$ & $(14.99)$ & $(15.20)$ & $(15.09)$ & $(14.74)$ \\
$R^{2}$ & $(5.32)$ & 1.46 & 1.44 & 1.20 & 1.02 & 0.72 \\
& 0.20 & $0.52)$ & $(6.57)$ & $(6.37)$ & $(5.44)$ & $(4.86)$ \\
\hline \hline
\end{tabular}

Legend: The regressors are obtained by summing the explanatory variables in table II that are significant at the $5 \%$ level for each predictive $h .{ }^{a}$ Sum between crystals at D2, D4 and D5. ${ }^{b}$ Sum between crystals at D2, D3, D4 and D5. ${ }^{c}$ Sum between crystals at D3, D4 and D5. ${ }^{d}$ Sum between crystals at D4 and D5. Round brackets indicate $t$-ratios. 
TABLE IV:

Predictability tests on MODELS BASED ON THE FULl SAMPLE

\begin{tabular}{|c|c|c|c|c|c|c|c|c|c|c|c|c|c|}
\hline & \multirow[t]{3}{*}{ Statistic } & \multicolumn{6}{|c|}{ Unfiltered regressors } & \multicolumn{6}{|c|}{ Filtered regressors } \\
\hline & & \multicolumn{6}{|c|}{ Predictive $h$} & \multicolumn{6}{|c|}{ Predictive $h$} \\
\hline & & 2 & 4 & 6 & 8 & 10 & 12 & $2^{a}$ & $4^{b}$ & $6^{c}$ & $8^{c}$ & $10^{d}$ & $12^{a}$ \\
\hline & QLR & 33.14 & 53.17 & 9.23 & 13.46 & 6.69 & 14.76 & 23.31 & 22.1 & 41.13 & 23.64 & 12.54 & 11.27 \\
\hline & p-value & 0 & 0 & 0.21 & 0.04 & 0.5 & 0.03 & 0 & 0 & 0 & 0 & 0.06 & 0.1 \\
\hline & Exp-W & 12.33 & 22.45 & 2.2 & 3.71 & 1.23 & 2.77 & 7.39 & 6.68 & 15.82 & 8.69 & 2.49 & 1.74 \\
\hline & $\mathrm{p}$-value & 0 & 0 & 0.32 & 0.08 & 0.71 & 0.18 & 0 & 0 & 0 & 0 & 0.24 & 0.47 \\
\hline & Nyblom & 3.44 & 6.49 & 0.61 & 1 & 0.37 & 0.32 & 0.78 & 1.6 & 3.64 & 1.31 & 0.54 & 0.31 \\
\hline & p-value & 0 & 0 & 0.42 & 0.13 & 0.76 & 0.84 & 0.26 & 0.02 & 0 & 0.04 & 0.51 & 0.85 \\
\hline & ENCsp & $172.09^{*}$ & 199.08* & -5.55 & -7.49 & -1.65 & $27.85^{*}$ & $19.96^{*}$ & $30.19^{*}$ & $170^{*}$ & $116.06^{*}$ & $122.19^{*}$ & $19.21^{*}$ \\
\hline & ENCre & $227.1^{*}$ & $413.94^{*}$ & -0.95 & -2.99 & $4.13^{*}$ & $30.23^{*}$ & $21.19^{*}$ & $39.14^{*}$ & $216.52^{*}$ & $111.67^{*}$ & $142.44^{*}$ & $47.97^{*}$ \\
\hline & ENCro & $240.38^{*}$ & $444.52^{*}$ & -1.82 & -3 & $6.04^{*}$ & $30.17^{*}$ & $22.12^{*}$ & $41.93^{*}$ & $240^{*}$ & $107.29 *$ & $123.65^{*}$ & $40.03^{*}$ \\
\hline
\end{tabular}

Legend: Models for predictive $h$ s from 1 to 5 quarters ahead, and for 11 quarters ahead use non-differenced variables. All other models are based on data in first difference. The filtered regressors are obtained by summing the explanatory variables from the level regressions that are significant at the $5 \%$ level for each predictive $h$. ${ }^{a}$ Sum between crystals at D2, D4 and D5. ${ }^{b}$ Sum between crystals at D2, D3, D4 and D5. ${ }^{c}$ Sum between crystals at D3, D4 and D5. ${ }^{d}$ Sum between crystals at D4 and D5. This table reports the following test statistics and p-values. A series of tests for a one-time structural break: Andrews (1993) test, labeled QLR, Andrews and Ploberger (1994) tests, labeled Exp-W and Mean-W, Nyblom (1989) test, labeled Nyblom. A series of tests for out-of-sample relative forecast comparisons: the test for forecasting comparisons for nested models discussed by Clark and McCracken (2001), labeled ENC-NEW. The latter tests are applied to rolling, recursive and fixed forecasting schemes, respectively labeled with the following subscripts: roll, rec, and fix. ${ }^{*}$ Significant at the $1 \%$ level. ${ }^{* *}$ Significant at the $5 \%$ level. ${ }^{* * *}$ Significant at the $10 \%$ level. 
TABLE V:

LEVEL REGRESSiONS, FULL SAMPLE

\begin{tabular}{|c|c|c|c|c|c|c|c|}
\hline & A6 & D1 & D2 & D3 & D4 & D5 & D6 \\
\hline \multicolumn{8}{|c|}{$h: 2$} \\
\hline$\hat{\alpha}$ & $\begin{array}{c}3.95 \\
(17.60)\end{array}$ & $\begin{array}{l}0.001 \\
(0.03)\end{array}$ & $\begin{array}{l}-0.01 \\
(-0.11)\end{array}$ & $\begin{array}{l}0.01 \\
(0.02)\end{array}$ & $\begin{array}{l}0.13 \\
(0.68)\end{array}$ & $\begin{array}{l}0.03 \\
(0.26)\end{array}$ & $\begin{array}{l}0.06 \\
(1.31)\end{array}$ \\
\hline$\hat{\beta}$ & $\begin{array}{l}-0.64 \\
(-4.66)\end{array}$ & $\begin{array}{l}0.35 \\
(1.56)\end{array}$ & $\begin{array}{l}1.35 \\
(2.96)\end{array}$ & $\begin{array}{l}1.04 \\
(1.74)\end{array}$ & $\begin{array}{l}1.17 \\
(4.79)\end{array}$ & $\begin{array}{l}0.39 \\
(1.97)\end{array}$ & $\begin{array}{l}-0.69 \\
(-2.90)\end{array}$ \\
\hline$R^{2}$ & 0.23 & 0.02 & 0.11 & 0.03 & 0.21 & 0.05 & 0.13 \\
\hline \multicolumn{8}{|c|}{$h: 4$} \\
\hline$\hat{\alpha}$ & $\begin{array}{c}3.98 \\
(14.14)\end{array}$ & $\begin{array}{l}0.001 \\
(0.10)\end{array}$ & $\begin{array}{l}0.01 \\
(0.25)\end{array}$ & $\begin{array}{l}-0.01 \\
(-0.09)\end{array}$ & $\begin{array}{l}0.13 \\
(0.63)\end{array}$ & $\begin{array}{l}0.05 \\
(0.28)\end{array}$ & $\begin{array}{l}0.07 \\
(1.09)\end{array}$ \\
\hline$\hat{\beta}$ & $\begin{array}{l}-0.65 \\
(-3.71)\end{array}$ & $\begin{array}{l}-0.10 \\
(-1.15)\end{array}$ & $\begin{array}{l}0.81 \\
(2.67)\end{array}$ & $\begin{array}{l}1.70 \\
(2.57)\end{array}$ & $\begin{array}{l}1.37 \\
(5.67)\end{array}$ & $\begin{array}{l}0.59 \\
(3.02)\end{array}$ & $\begin{array}{l}-0.76 \\
(-2.58)\end{array}$ \\
\hline$R^{2}$ & 0.26 & 0.01 & 0.15 & 0.12 & 0.32 & 0.13 & 0.16 \\
\hline \multicolumn{8}{|c|}{$h: 6$} \\
\hline$\hat{\alpha}$ & $\begin{array}{l}4.00 \\
(12.55)\end{array}$ & $\underset{(0.02)}{0.0001}$ & $\begin{array}{l}0.001 \\
(0.08)\end{array}$ & $\begin{array}{l}-0.03 \\
(-0.35)\end{array}$ & $\begin{array}{l}0.10 \\
(0.57)\end{array}$ & $\begin{array}{l}0.05 \\
(0.32)\end{array}$ & $\begin{array}{l}0.07 \\
(1.00)\end{array}$ \\
\hline$\hat{\beta}$ & $\begin{array}{l}-0.66 \\
(-3.26)\end{array}$ & $\begin{array}{l}-0.05 \\
(-0.71)\end{array}$ & $\begin{array}{l}0.22 \\
(2.36)\end{array}$ & $\begin{array}{l}1.50 \\
(2.99)\end{array}$ & $\begin{array}{l}1.35 \\
(6.12)\end{array}$ & $\begin{array}{l}0.77 \\
(4.81)\end{array}$ & $\begin{array}{l}-0.83 \\
(-2.55)\end{array}$ \\
\hline$R^{2}$ & 0.28 & 0.004 & 0.05 & 0.17 & 0.39 & 0.22 & 0.19 \\
\hline \multicolumn{8}{|l|}{$h: 8$} \\
\hline$\hat{\alpha}$ & $\begin{array}{l}4.02 \\
(11.65)\end{array}$ & $\begin{array}{l}-0.001 \\
(-0.20)\end{array}$ & $\begin{array}{l}-0.004 \\
(-0.47)\end{array}$ & $\begin{array}{l}-0.01 \\
(-0.35)\end{array}$ & $\begin{array}{l}0.06 \\
(0.43)\end{array}$ & $\begin{array}{l}0.06 \\
(0.36)\end{array}$ & $\begin{array}{l}0.07 \\
(0.96)\end{array}$ \\
\hline$\hat{\beta}$ & $\begin{array}{l}-0.66 \\
(-2.99)\end{array}$ & $\begin{array}{c}0.05 \\
(1.00)\end{array}$ & $\begin{array}{l}0.23 \\
(2.79)\end{array}$ & $\begin{array}{l}0.86 \\
(2.43)\end{array}$ & $\begin{array}{l}1.15 \\
(6.27)\end{array}$ & $\begin{array}{c}0.91 \\
(7.51)\end{array}$ & $\begin{array}{l}-0.88 \\
(-2.65)\end{array}$ \\
\hline$R^{2}$ & 0.30 & 0.01 & 0.07 & 0.12 & 0.38 & 0.33 & 0.22 \\
\hline \multicolumn{8}{|c|}{$h: 10$} \\
\hline$\hat{\alpha}$ & $\begin{array}{c}4.03 \\
(11.09)\end{array}$ & $\begin{array}{c}0.0002 \\
(0.10)\end{array}$ & $\begin{array}{c}-0.002 \\
(-0.29)\end{array}$ & $\begin{array}{l}0.0002 \\
(-0.10)\end{array}$ & $\begin{array}{l}0.03 \\
(0.26)\end{array}$ & $\begin{array}{l}0.06 \\
(0.41)\end{array}$ & $\begin{array}{c}0.08 \\
(0.94)\end{array}$ \\
\hline$\hat{\beta}$ & $\begin{array}{l}-0.66 \\
(-2.83)\end{array}$ & $\begin{array}{l}-0.01 \\
(-0.45)\end{array}$ & $\begin{array}{l}0.24 \\
(2.64)\end{array}$ & $\begin{array}{c}0.35 \\
(1.57)\end{array}$ & $\begin{array}{c}0.83 \\
(5.64)\end{array}$ & $\begin{array}{c}1.00 \\
(10.47)\end{array}$ & $\begin{array}{l}-0.93 \\
(-2.84)\end{array}$ \\
\hline$R^{2}$ & 0.31 & 0.001 & 0.11 & 0.04 & 0.30 & 0.44 & 0.25 \\
\hline \multicolumn{8}{|c|}{$h: 12$} \\
\hline$\overline{\hat{\alpha}}$ & $\begin{array}{c}4.04 \\
(10.73)\end{array}$ & $\begin{array}{c}-0.0003 \\
(-0.13)\end{array}$ & $\begin{array}{l}0.002 \\
(0.39)\end{array}$ & $\begin{array}{c}-0.0003 \\
(-0.17)\end{array}$ & $\begin{array}{l}0.01 \\
(0.14)\end{array}$ & $\begin{array}{c}0.06 \\
(0.46)\end{array}$ & $\begin{array}{l}0.08 \\
(0.93)\end{array}$ \\
\hline$\hat{\beta}$ & $\begin{array}{l}-0.65 \\
(-2.72)\end{array}$ & $\begin{array}{l}0.04 \\
(1.77)\end{array}$ & $\begin{array}{l}0.20 \\
(2.05)\end{array}$ & $\begin{array}{l}0.20 \\
(1.16)\end{array}$ & $\begin{array}{l}0.50 \\
(4.30)\end{array}$ & $\begin{array}{c}1.05 \\
(13.14)\end{array}$ & $\begin{array}{l}-0.98 \\
(-3.10)\end{array}$ \\
\hline$R^{2}$ & 0.33 & 0.01 & 0.10 & 0.03 & 0.16 & 0.54 & 0.28 \\
\hline
\end{tabular}

Legend: Round brackets indicate $t$-values. 
TABLE VI:

LEVEL REGRESSIONS, PRE-1985 SUBSAMPLE

\begin{tabular}{|c|c|c|c|c|c|c|c|}
\hline & A 6 & D1 & D2 & D3 & D4 & D5 & D6 \\
\hline \multicolumn{8}{|c|}{$h: 2$} \\
\hline$\hat{\alpha}$ & $\begin{array}{c}4.67 \\
(20.19)\end{array}$ & $\begin{array}{l}0.001 \\
(0.03)\end{array}$ & $\begin{array}{l}-0.01 \\
(-0.07)\end{array}$ & $\begin{array}{l}0.01 \\
(0.04)\end{array}$ & $\begin{array}{l}0.24 \\
(0.87)\end{array}$ & $\begin{array}{l}-0.09 \\
(-0.67)\end{array}$ & $\begin{array}{l}0.002 \\
(0.03)\end{array}$ \\
\hline$\hat{\beta}$ & $\begin{array}{l}-1.33 \\
(-6.23)\end{array}$ & $\begin{array}{l}0.41 \\
(1.89)\end{array}$ & $\begin{array}{l}1.97 \\
(3.94)\end{array}$ & $\begin{array}{l}1.58 \\
(1.30)\end{array}$ & $\begin{array}{l}1.59 \\
(4.75)\end{array}$ & $\begin{array}{l}0.45 \\
(2.21)\end{array}$ & $\begin{array}{l}-1.05 \\
(-3.91)\end{array}$ \\
\hline$R^{2}$ & 0.43 & 0.03 & 0.19 & 0.04 & 0.28 & 0.11 & 0.23 \\
\hline \multicolumn{8}{|c|}{$h: 4$} \\
\hline$\hat{\alpha}$ & $\begin{array}{c}4.67 \\
(16.10)\end{array}$ & $\begin{array}{l}0.002 \\
(0.12)\end{array}$ & $\begin{array}{l}0.01 \\
(0.37)\end{array}$ & $\begin{array}{l}0.00 \\
(-0.01)\end{array}$ & $\begin{array}{l}0.20 \\
(0.76)\end{array}$ & $\begin{array}{l}-0.08 \\
(-0.51)\end{array}$ & $\begin{array}{c}0.01 \\
(0.11)\end{array}$ \\
\hline$\hat{\beta}$ & $\begin{array}{l}-1.32 \\
(-5.03)\end{array}$ & $\begin{array}{l}-0.09 \\
(-0.86)\end{array}$ & $\begin{array}{l}1.17 \\
(4.52)\end{array}$ & $\begin{array}{l}3.04 \\
(2.55)\end{array}$ & $\begin{array}{l}1.76 \\
(5.10)\end{array}$ & $\begin{array}{c}0.65 \\
(3.31)\end{array}$ & $\begin{array}{l}-1.10 \\
(-3.37)\end{array}$ \\
\hline$R^{2}$ & 0.45 & 0.01 & 0.27 & 0.20 & 0.39 & 0.23 & 0.25 \\
\hline \multicolumn{8}{|c|}{$h: 6$} \\
\hline$\hat{\alpha}$ & $\begin{array}{c}4.66 \\
(14.18)\end{array}$ & $\begin{array}{c}0.0005 \\
(0.05)\end{array}$ & $\begin{array}{c}0.003 \\
(0.21)\end{array}$ & $\begin{array}{l}-0.01 \\
(-0.13)\end{array}$ & $\begin{array}{l}0.16 \\
(0.68)\end{array}$ & $\begin{array}{l}-0.07 \\
(-0.43)\end{array}$ & $\begin{array}{l}0.02 \\
(0.17)\end{array}$ \\
\hline$\hat{\beta}$ & $\begin{array}{l}-1.30 \\
(-4.48)\end{array}$ & $\begin{array}{l}-0.04 \\
(-0.60)\end{array}$ & $\begin{array}{l}0.31 \\
(3.31)\end{array}$ & $\begin{array}{l}2.73 \\
(4.16)\end{array}$ & $\begin{array}{l}1.68 \\
(5.15)\end{array}$ & $\begin{array}{l}0.82 \\
(5.53)\end{array}$ & $\begin{array}{l}-1.14 \\
(-3.27)\end{array}$ \\
\hline$R^{2}$ & 0.47 & 0.003 & 0.10 & 0.31 & 0.45 & 0.37 & 0.28 \\
\hline \multicolumn{8}{|c|}{$h: 8$} \\
\hline$\hat{\alpha}$ & $\begin{array}{c}4.64 \\
(13.07)\end{array}$ & $\begin{array}{c}-0.00001 \\
(-0.003)\end{array}$ & $\begin{array}{c}-0.004 \\
(-0.35)\end{array}$ & $\begin{array}{l}-0.01 \\
(-0.25)\end{array}$ & $\begin{array}{l}0.10 \\
(0.54)\end{array}$ & $\begin{array}{l}-0.06 \\
(-0.39)\end{array}$ & $\begin{array}{c}0.02 \\
(0.22)\end{array}$ \\
\hline$\hat{\beta}$ & $\begin{array}{l}-1.28 \\
(-4.19)\end{array}$ & $\begin{array}{l}0.07 \\
(1.44)\end{array}$ & $\begin{array}{l}0.32 \\
(4.66)\end{array}$ & $\begin{array}{l}1.61 \\
(4.21)\end{array}$ & $\begin{array}{l}1.40 \\
(5.12)\end{array}$ & $\begin{array}{l}0.95 \\
(9.47)\end{array}$ & $\begin{array}{l}-1.18 \\
(-3.36)\end{array}$ \\
\hline$R^{2}$ & 0.48 & 0.01 & 0.13 & 0.24 & 0.43 & 0.51 & 0.30 \\
\hline \multicolumn{8}{|c|}{$h: 10$} \\
\hline$\hat{\alpha}$ & $\begin{array}{c}4.63 \\
(12.34)\end{array}$ & $\underset{(0.06)}{0.0002}$ & $\begin{array}{l}-0.002 \\
(-0.18)\end{array}$ & $\begin{array}{l}-0.01 \\
(-0.33)\end{array}$ & $\begin{array}{l}0.06 \\
(0.38)\end{array}$ & $\begin{array}{l}-0.04 \\
(-0.35)\end{array}$ & $\begin{array}{l}0.03 \\
(0.25)\end{array}$ \\
\hline$\hat{\beta}$ & $\begin{array}{l}-1.25 \\
(-4.01)\end{array}$ & $\begin{array}{c}-0.006 \\
(-0.21)\end{array}$ & $\begin{array}{l}0.33 \\
(4.07)\end{array}$ & $\begin{array}{l}0.69 \\
(2.25)\end{array}$ & $\begin{array}{l}1.00 \\
(4.58)\end{array}$ & $\begin{array}{c}1.05 \\
(13.97)\end{array}$ & $\begin{array}{l}-1.22 \\
(-3.57)\end{array}$ \\
\hline$R^{2}$ & 0.49 & 0.0002 & 0.20 & 0.10 & 0.33 & 0.64 & 0.33 \\
\hline \multicolumn{8}{|c|}{$h: 12$} \\
\hline$\hat{\alpha}$ & $\begin{array}{c}4.60 \\
(11.83)\end{array}$ & $\begin{array}{c}0.0003 \\
(0.10)\end{array}$ & $\begin{array}{l}0.004 \\
(0.56)\end{array}$ & $\begin{array}{l}-0.01 \\
(-0.46)\end{array}$ & $\begin{array}{l}0.03 \\
(0.25)\end{array}$ & $\begin{array}{l}-0.03 \\
(-0.30)\end{array}$ & $\begin{array}{c}0.03 \\
(0.28)\end{array}$ \\
\hline$\hat{\beta}$ & $\begin{array}{l}-1.22 \\
(-3.90)\end{array}$ & $\begin{array}{l}0.05 \\
(2.15)\end{array}$ & $\begin{array}{l}0.29 \\
(3.50)\end{array}$ & $\begin{array}{l}0.43 \\
(1.67)\end{array}$ & $\begin{array}{l}0.59 \\
(3.45)\end{array}$ & $\begin{array}{l}1.09 \\
(16.59)\end{array}$ & $\begin{array}{l}-1.25 \\
(-3.87)\end{array}$ \\
\hline$R^{2}$ & 0.49 & 0.02 & 0.19 & 0.07 & 0.17 & 0.74 & 0.35 \\
\hline
\end{tabular}

Legend: Round brackets indicate $t$-values. 
TABLE VII:

Predictive models With LeVel Regressors, Post-1985 SubSAmple

\begin{tabular}{|c|c|c|c|c|c|c|c|c|}
\hline & Unfiltered & A6 & D1 & D2 & D3 & D4 & D5 & D6 \\
\hline \multicolumn{9}{|l|}{$h: 2$} \\
\hline$\hat{\alpha}$ & $\begin{array}{l}2.43 \\
(3.86)\end{array}$ & $\begin{array}{l}3.16 \\
(1.34)\end{array}$ & $\begin{array}{l}3.05 \\
(9.30)\end{array}$ & $\begin{array}{l}3.05 \\
(9.23)\end{array}$ & $\begin{array}{l}3.07 \\
(9.64)\end{array}$ & $\begin{array}{c}3.07 \\
(10.42)\end{array}$ & $\begin{array}{l}3.04 \\
(9.32)\end{array}$ & $\begin{array}{l}3.14 \\
(8.99)\end{array}$ \\
\hline$\hat{\beta}$ & $\begin{array}{l}0.36 \\
(1.56)\end{array}$ & $\begin{array}{l}-0.06 \\
(-0.05)\end{array}$ & $\begin{array}{l}-0.96 \\
(-1.09)\end{array}$ & $\begin{array}{l}-0.16 \\
(-0.21)\end{array}$ & $\begin{array}{l}1.23 \\
(1.69)\end{array}$ & $\begin{array}{l}0.91 \\
(1.71)\end{array}$ & $\begin{array}{l}-0.13 \\
(-0.35)\end{array}$ & $\begin{array}{l}-1.68 \\
(-0.67)\end{array}$ \\
\hline$R^{2}$ & 0.06 & 0.0001 & 0.01 & 0.0007 & 0.09 & 0.12 & 0.00 & 0.02 \\
\hline \multicolumn{9}{|l|}{$h: 4$} \\
\hline$\hat{\alpha}$ & $\begin{array}{l}2.49 \\
(3.26)\end{array}$ & $\begin{array}{c}3.92 \\
(1.57)\end{array}$ & $\begin{array}{l}3.07 \\
(9.09)\end{array}$ & $\begin{array}{l}3.07 \\
(9.10)\end{array}$ & $\begin{array}{l}3.07 \\
(9.10)\end{array}$ & $\begin{array}{c}3.12 \\
(11.80)\end{array}$ & $\begin{array}{l}3.07 \\
(9.69)\end{array}$ & $\begin{array}{l}3.21 \\
(9.61)\end{array}$ \\
\hline$\hat{\beta}$ & $\begin{array}{l}0.34 \\
(1.21)\end{array}$ & $\begin{array}{l}-0.48 \\
(-0.35)\end{array}$ & $\begin{array}{l}-0.17 \\
(-0.30)\end{array}$ & $\begin{array}{l}-0.11 \\
(-0.13)\end{array}$ & $\begin{array}{c}0.36 \\
(0.66)\end{array}$ & $\begin{array}{l}1.18 \\
(2.68)\end{array}$ & $\begin{array}{l}0.00 \\
(0.00)\end{array}$ & $\begin{array}{l}-2.30 \\
(-0.89)\end{array}$ \\
\hline$R^{2}$ & 0.07 & 0.01 & 0.0004 & 0.0004 & 0.01 & 0.28 & 0.00 & 0.06 \\
\hline \multicolumn{9}{|l|}{$h: 6$} \\
\hline$\hat{\alpha}$ & $\begin{array}{l}2.64 \\
(3.10)\end{array}$ & $\begin{array}{l}4.74 \\
(2.07)\end{array}$ & $\begin{array}{l}3.10 \\
(9.35)\end{array}$ & $\begin{array}{l}3.11 \\
(9.35)\end{array}$ & $\begin{array}{l}3.11 \\
(9.36)\end{array}$ & $\begin{array}{l}3.15 \\
(11.55)\end{array}$ & $\begin{array}{c}3.12 \\
(10.28)\end{array}$ & $\begin{array}{c}3.30 \\
(11.80)\end{array}$ \\
\hline$\hat{\beta}$ & $\begin{array}{l}0.26 \\
(0.84)\end{array}$ & $\begin{array}{l}-0.90 \\
(-0.71)\end{array}$ & $\begin{array}{l}-0.45 \\
(-1.04)\end{array}$ & $\begin{array}{l}-0.43 \\
(-1.43)\end{array}$ & $\begin{array}{l}-0.33 \\
(-0.68)\end{array}$ & $\begin{array}{l}1.11 \\
(3.21)\end{array}$ & $\begin{array}{l}0.20 \\
(0.55)\end{array}$ & $\begin{array}{l}-2.96 \\
(-1.31)\end{array}$ \\
\hline$R^{2}$ & 0.05 & 0.05 & 0.003 & 0.01 & 0.01 & 0.35 & 0.01 & 0.13 \\
\hline \multicolumn{9}{|l|}{$h: 8$} \\
\hline$\hat{\alpha}$ & $\begin{array}{l}2.75 \\
(3.11)\end{array}$ & $\begin{array}{l}5.56 \\
(2.78)\end{array}$ & $\begin{array}{l}3.13 \\
(9.60)\end{array}$ & $\begin{array}{l}3.14 \\
(9.60)\end{array}$ & $\begin{array}{l}3.14 \\
(9.43)\end{array}$ & $\begin{array}{c}3.16 \\
(10.82)\end{array}$ & $\begin{array}{c}3.17 \\
(10.88)\end{array}$ & $\begin{array}{c}3.40 \\
(15.20)\end{array}$ \\
\hline$\hat{\beta}$ & $\begin{array}{l}0.21 \\
(0.67)\end{array}$ & $\begin{array}{l}-1.32 \\
(-1.19)\end{array}$ & $\begin{array}{l}-0.27 \\
(-1.05)\end{array}$ & $\begin{array}{l}-0.54 \\
(-1.60)\end{array}$ & $\begin{array}{l}-0.22 \\
(-0.37)\end{array}$ & $\begin{array}{l}0.86 \\
(3.31)\end{array}$ & $\begin{array}{c}0.41 \\
(1.21)\end{array}$ & $\begin{array}{l}-3.59 \\
(-1.97)\end{array}$ \\
\hline$R^{2}$ & 0.04 & 0.12 & 0.002 & 0.02 & 0.01 & 0.28 & 0.05 & 0.25 \\
\hline \multicolumn{9}{|c|}{$h: 10$} \\
\hline$\hat{\alpha}$ & $\begin{array}{l}2.78 \\
(3.51)\end{array}$ & $\begin{array}{l}6.26 \\
(3.60)\end{array}$ & $\begin{array}{l}3.15 \\
(9.73)\end{array}$ & $\begin{array}{l}3.15 \\
(9.73)\end{array}$ & $\begin{array}{l}3.15 \\
(9.69)\end{array}$ & $\begin{array}{c}3.16 \\
(10.41)\end{array}$ & $\begin{array}{c}3.20 \\
(11.43)\end{array}$ & $\begin{array}{c}3.49 \\
(19.08)\end{array}$ \\
\hline$\hat{\beta}$ & $\begin{array}{l}0.20 \\
(0.80)\end{array}$ & $\begin{array}{l}-1.67 \\
(-1.73)\end{array}$ & $\begin{array}{l}-0.29 \\
(-1.27)\end{array}$ & $\begin{array}{l}-0.07 \\
(-0.35)\end{array}$ & $\begin{array}{l}0.08 \\
(0.22)\end{array}$ & $\begin{array}{l}0.55 \\
(2.35)\end{array}$ & $\begin{array}{c}0.62 \\
(2.00)\end{array}$ & $\begin{array}{l}-4.10 \\
(-2.89)\end{array}$ \\
\hline$R^{2}$ & 0.05 & 0.21 & 0.002 & 0.0003 & 0.00 & 0.14 & 0.13 & 0.39 \\
\hline \multicolumn{9}{|c|}{$h: 12$} \\
\hline$\hat{\alpha}$ & $\begin{array}{l}2.83 \\
(4.16)\end{array}$ & $\begin{array}{l}6.83 \\
(4.36)\end{array}$ & $\begin{array}{l}3.14 \\
(9.79)\end{array}$ & $\begin{array}{l}3.14 \\
(9.79)\end{array}$ & $\begin{array}{l}3.15 \\
(9.77)\end{array}$ & $\begin{array}{c}3.14 \\
(10.12)\end{array}$ & $\begin{array}{c}3.20 \\
(12.15)\end{array}$ & $\begin{array}{c}3.54 \\
(21.21)\end{array}$ \\
\hline$\hat{\beta}$ & $\begin{array}{l}0.16 \\
(0.86)\end{array}$ & $\begin{array}{l}-1.97 \\
(-2.29)\end{array}$ & $\begin{array}{l}-0.14 \\
(-0.77)\end{array}$ & $\begin{array}{l}-0.01 \\
(-0.06)\end{array}$ & $\begin{array}{l}0.17 \\
(0.76)\end{array}$ & $\begin{array}{l}0.29 \\
(1.15)\end{array}$ & $\begin{array}{l}0.75 \\
(2.97)\end{array}$ & $\begin{array}{l}-4.44 \\
(-3.78)\end{array}$ \\
\hline$R^{2}$ & 0.04 & 0.29 & 0.0007 & $1.5 \mathrm{e}-5$ & 0.01 & 0.05 & 0.24 & 0.50 \\
\hline
\end{tabular}

Legend: Round brackets indicate $t$-values. 